\title{
The Inscribed Metal Pots in the West of the Arab Gulf (Mleiha and Al- Fueda), Mesopotamia and Ancient Egypt: A Comparative Study
}

\author{
Waleed Mohamed Saffaie ${ }^{1}$ \\ ${ }^{1}$ History Division, Social Science Department, Faculty of Arts, Bahrain University, Bahrain \\ Correspondence: Waleed Mohamed Saffaie, History Division, Social Science Department, Faculty of Arts, \\ Bahrain University, Bahrain. E-mail: sawaleed63@gmail.com
}

Received: September 7, 2018

doi:10.5539/ass.v14n10p102
Accepted: September 24, $2018 \quad$ Online Published: September 28, 2018

URL: https://doi.org/10.5539/ass.v14n10p102

\begin{abstract}
The current study seeks to analyze some themes and ornaments that appeared on metal pots in the west of Arab Gulf (Mleiha in the United Arab Emirates and Al- Fueda in the Sultana of Oman). The study also makes a comparison between the metal pots of previous regions and their counterparts in Mesopotamia and Ancient Egypt. The Arab Gulf is of great importance because it represents an important center for commercial convoys and associates with ancient civilizations in Mesopotamia, ancient Egypt and other civilizations. The Arab Gulf produced a varied and splendid art with artistic output. On the other hand, Mesopotamia transferred the ancient Egyptian artistic influences to the Arab Gulf. The study highlights the two regions of Mlieha and Al- Fueda in the west of the Arab Gulf, Mesopotamia and Ancient Egypt. Also, it shows the artistic influences on these pots. To describe and analyze such metal pots, the study adopts the descriptive analytical approach. The researcher has faced several difficulties, which are: 1) Finding a few of inscribed metal pots led to the difficulty of the local comparison where some sites did not reveal a rich metal product. 2) The scarcity of references and books specialized in metal arts in the Arab library. 3) Numerous metal sculpture works have been lost due to re- using and re- shaping these metals again. The study has reached many conclusions, the most important of which are: 1) The pots and plates were decorated with splendid inscriptions and ornaments, and their themes were quoted from neighboring countries. 2) The Study has noted that some metal inscriptions represented the pure local environment of the art at the time. Also, some of them were affected by the arts of neighboring civilizations in Mesopotamia, Syria and ancient Egypt.
\end{abstract}

Keywords: metal pots, Mlieha, Al- Fueda, Mesopotamia, Ancient Egypt

\section{Introduction}

Undoubtedly, the humanitarian use of metals is one of the major cultural revolutions in the history of the mankind, no less important than the revolution of the discovery of agriculture and writing in ancient times. Despite the great importance of the metals in human civilizations in general and in the ancient Near East in particular, it has not been given enough attention and study by the researchers of the history and civilization of the ancient Near East. The Arabian Peninsula and the Arab Gulf gained special importance as they are important centers for commercial convoys that have been stationed in several locations in the North, South, East and West. On the other hand, the civilization of Mesopotamia and ancient Egypt are of great importance as they are the oldest civilizations in the ancient Near East and they have commercial, political and military relations with the Arab Peninsula and the Arab Gulf over the ages. This was evident in the mixing of the arts in the Arabian Peninsula and the Arab Gulf with the arts of Mesopotamia and ancient Egypt at the time, resulting in a varied and magnificent art. Due to the artistic outputs and products of this region, there was a dire need to study them and identify their artistic and impacts on neighboring civilizations.

Few metal were found in the Arab Peninsula and the Arab Gulf region. In contrast, many of various metal pots were found in Mesopotamia and ancient Egypt during ancient times. This may be due to the natural conditions and geographical and climatic factors of the Arabian Peninsula and the Arab Gulf, which made the metal monuments of both regions rare and few, especially, the factors of humidity and creeping the waters of the Gulf towards the old settlements. The Gulf region played a key role in forming the areas of settlement of ancient civilizations on the west coast of the Arab Gulf at the time.

There were several types of metal pots in the Arabian Peninsula and the Arab Gulf. For example, there were 
simple metal pots, which are circular pots with circular bases. They expand gradually towards edges. There were also engraved pots with ornaments of animals, plants and geometric forms. In addition, there were crushed pots and in poor state of preservation.

However, the study of the types and inscriptions showed that some of them represented the pure local environment of art at the time, and some others were affected by the arts of neighboring civilizations in Iran, the Indus Valley, Mesopotamia and ancient Egypt in the West.

The mining industry moved to the service of the arts. Various bronze pots were manufactured by forging. Perhaps the use of decoration in the Arabian Peninsula had Eastern Hellenistic origins that were absorbed by the Roman culture afterwards.

There have been numerous and varied themes such as the scenes of animals, the ornaments of plants, the scenes of individuals and the scenes of combat and military wheels. Additionally, there have been scenes affected by the Aegean style, which depicts heroes struggling with mythical animals.

Accordingly, the study deals with the inscribed metal pots in the west of the Gulf region, Mesopotamia and ancient Egypt. The study also is an analytical study of the most important artistic themes that appeared on the pots. It is divided into three sections. The first section deals with the inscribed metal pots in the West of the Arab Gulf (at Mleiha region in United Arab Emirates and at Al- Fuaida in Oman Sultanate). The second addresses the inscribed metal pots in Mesopotamia. The third tackles the inscribed metal pots in ancient Egypt.

\section{2- The Inscribed Metal Pots in the West of the Arab Gulf}

\section{1 Mleiha Area}

\subsubsection{Remains of an Inscribed Bronze Pot}

Remains of bronze pots were found at Mleiha area in the United Arab Emirates, dated to the end of $3^{\text {rd }}$ century (B. C.) and the beginning $2^{\text {nd }}$ century (the end of the first millennium B. C.), as shown in Figure 1.

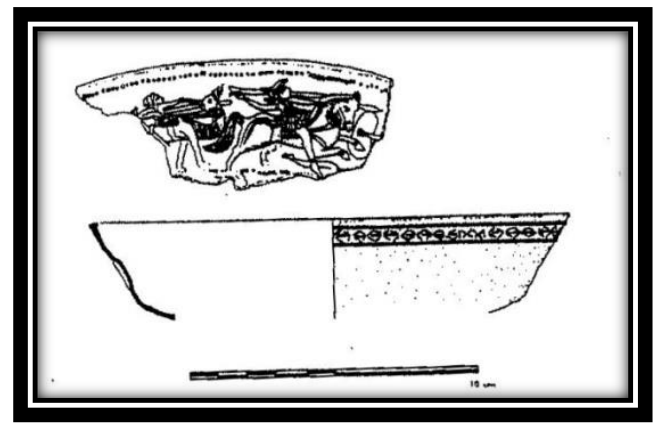

Figure 1. Inscribed Metal Pots at Mleiha Area

Source: Boucharlat, R., Jarczynske, P., "The Mleiha Area - An Archaeological Map", ASISE 4 (1988) p. 64; fig. $2714,15$.

The first fragment represents small shapes and drawings at the upper edge of the pot, which depict a scene of a battle. These drawings depict two warriors dressed in war clothes, one of them was riding a horse and was holding a spear in his left hand, and the other was riding a camel and was holding a bayonet in his left hand, and the other was riding a camel and was holding a bayonet in his left hand. The two animals also were in a case of running (Boucharlat \& Jarczynske, 1988). These landscapes spread in both Mesopotamia and ancient Egypt. Smith sees that the fast- paced and jumping animal movement in the air is an Aegean artistic style. While Kantor believes that the style of portraying animals jumping in the air appeared first in the Egyptian art since the age of pre- families until the end of the middle state, and during the age of the modern state (Kontor, 1947).

The depiction of running animals on the pots in the Arabian Peninsula, as shown in the magnificent inscriptions on the pots of mleiha and Al- Fueda (Boucharlat, 1991) may have been affected by the same artistic style of Mesopotamia school. Such style may be reached to Mesopotamia by Egypt where the depiction of running animals in ancient Egyptian art has old roots.

\subsubsection{Remains of Inscribed Bronze Pot}

A pot of bronze with animal, human and plant ornamental motifs were also found at Mleiha area, as shown in Figure 2 . The middle of the pot was decorated by a flower, which was surrounded by three inscribed rows. 


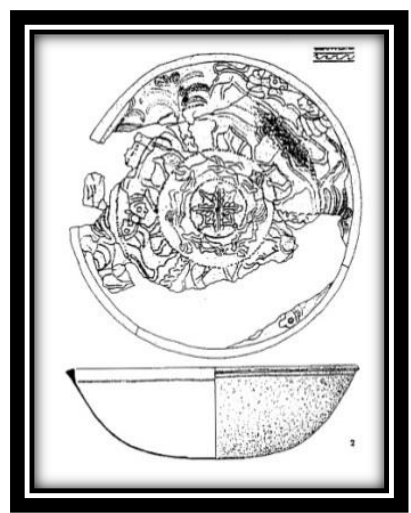

Figure 2. Inscribed Metal Pots at Mleiha Area

Source: Mouton, M., \& Boucharlat, R., \& Jarczynske, P., "Excavations at Mleiha, The Thired Season", ASIE 5 (1989), pp. 44-45; fig. 23 3, 24 1,2

Keimer believes that the ornamentation of the flower and the various compositions, which are common in the ancient arts, is of Egyptian origin. Keimer does not favor that the Egyptians arts derived the ornamentation of the flower from Mesopotamia. Rather, Keimer emphasizes that it is of Egyptian origin. Furthermore, Keimer confirms also that different and very similar combinations emerged in the motifs of the modern state, and that the treatment and dealing with the theme of flower motif in other civilizations was different (Keimer, 1924).

For example, both Chrysanthemum and Rosetta flowers emerged in the ornamentations of the ancient state. Also, the types of the blooming flowers emerged on the pots extracted from Al- Fueda and Mleiha in the Arabian Peninsula (Mouton \& Boucharlat, 1989). The flower of Rosetta is one the most important artistic elements that decorated the middle of the pots. This flower must have an origin in nature. The Egyptian artist put his touches and additions gradually on the flower of rosetta. Thus, the forms of this flower, which came to us, are closer to the geometric picture. It may be somewhat similar to margarita flower (Selim, 2001).

The first raw surrounding by the flower contains landscape representing human forms or individual, who crawl on their stomachs in a sequential position. They are wearing a short apron, and they apparently were crawling around this flower. The second row represents a set of opposite wild animals. The third row also represents a set of opposite animals. There has been a palm which separates each group from another. There were three palms which may represent Enki god. They separate all groups. The legal of the palm is based on the borders of the first row. These scenes also appeared on a similar pot in the ancient Near East (Mouton \& Boucharlat, 1989), especially in Mesopotamia and ancient Egypt.

\subsubsection{Remains of a Pot at Mleiha Area}

The remains of inscribed pot on which remains of animal ornamental motifs were found at Mleiha area (Figure 3).

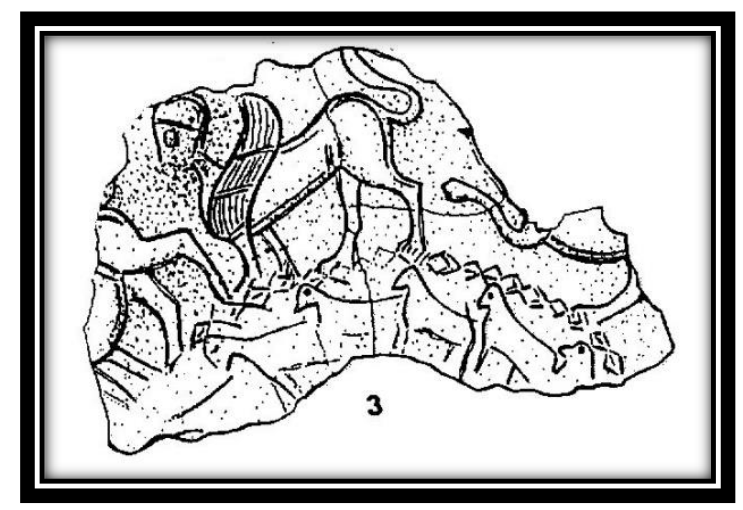

Figure 3.

The pot contains a scene of winged horses at the upper edge of the pot, while a scene of the herd of animals appears at the bottom of the pot. These scenes, which represent the forms of winged animals, spread in the countries of the ancient Near East. Boucharlat believes that some similar pots were found in Phoenicia. This pot 
was dated to the end of the first millennium (B.C.) (Bourcharlat \& Mouton, 1991). It is worth mentioning that the winged scenes had an Egyptian effect and some artistic additions at the time. Boucharlat thinks that there are winged forms in Phoenicia which are similar to the winged forms at Mleiha, dating to the end of the first millennium B. C. (Boucharlat \& Mouton, 1991). However, the study sees that the scenes representing the winged forms had an Egyptian effect, and the countries of the ancient Near East provided some artistic additions at the time.

\subsection{Al- Fueda Area}

\subsubsection{A Bronze Pot from Al- Fueda, The East of Oman Sultanate}

An inscribed bronze pot was found at Al- Fueda, Oman Sultanate. The diameter of the pot is $10 \mathrm{~cm}$ (Figure 4).

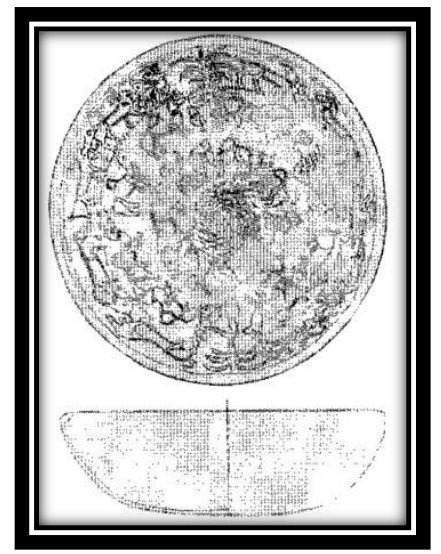

Figure 4.

This pots shows three rows of human, animal and plant ornamental motifs. The middle of the pot was decorated by a flower. The first row was surrounded by this flower. The first row contains a set of animal ornamental motifs, which represent horses and camels in a state of walking (Paul \& Charlotte, 2001). Keimer believes that the forms of flowers are of Egyptian origin, and Mesopotamia and Phoenicia derived these forms from Egypt afterwards (Keimer, 1924). The second row also consists of a set of animal ornamental motifs, which represent a set of horses, camels and caws. These animals also were in a state of working. The third row consists of animal and pland ornamental motifs also. This row also represents a set of animals in opposite position. Some of these animals have horns. The top and bottom of the pot was decorated by two palms. The two palms separate the animal and plant ornamental motifs. A person appears in front of the palm, and the palm here may refers to god Enzak, the son of god Enki. This scene depicts the person as if he was worshiping to god Enki.

\section{The Inscribed Metal Pots in Mesopotamia}

\subsection{A Pot of Bronze}

A large pot of bronze with a circular base raised from the middle of the pot was found in Nimrod (Figure 5).

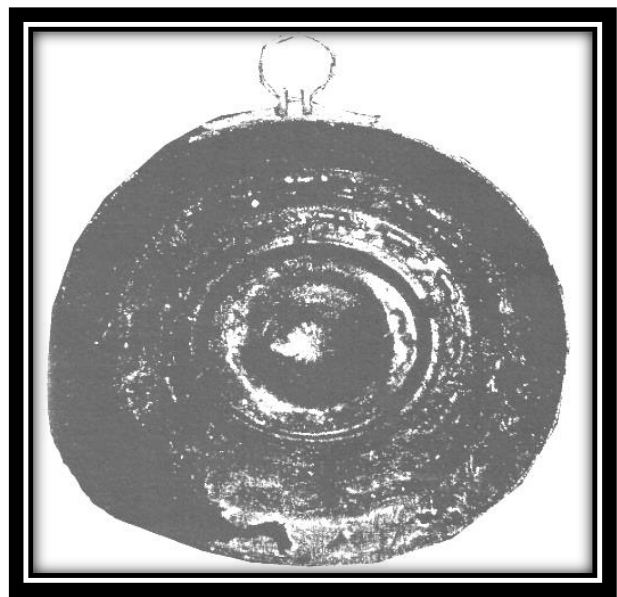

Figure 5. 
It is noticed that the shoulders of the pot seem to be rising outward. Accordingly, the handle in this pot has been fixed by two rings fixed with a brace by two screws from the outside of the rim in order to pass the ring handle inside the rings with all flexibility and ease. The pot lost some of its parts from the edge and sides. It is decorated with a variety of animal ornamental motifs. The center of the pot a blooming flower surrounded by three friezes, which have animal ornamental motifs representing diffused animals.

The middle frieze from the inside represents a set of winged calves, harts, deer and lions. A scene depicts one of these animals being attacked by lions. While the outer frieze depicts a group of calves in a state of successive walk. The inner frieze depicts a set of deer in a state of successive walk.

\subsection{A Deep Pot of Bronze}

A deep pot of bronze with a circular base and a gradually divergent edge from the outside. It is noted that some parts of edge and base have been lost. The middle of the pot was decorated with a blooming flower that surrounded by frieze of plant ornamental motifs representing the lotus flower. This frieze was surrounded by animal ornamental motifs representing eagles and animals, which are likely wild pigs (Figure 6).

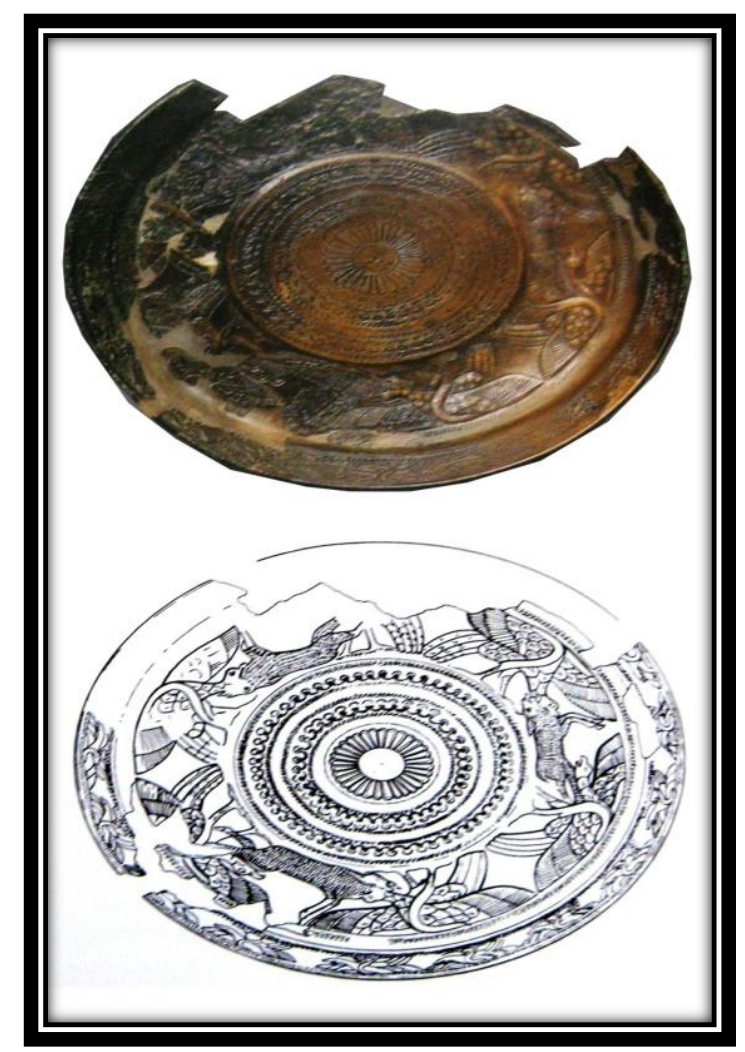

Figure 6.

There are ornaments of a set of eagles around the upper edge from inside. There are five Semitic letters from the outside. Barnet believes that the floral ornaments that decorate this pot have a Syrian nature. The scenes of eagles were common in the ancient Near East where they were clearly shown through the Assyrian inscriptions and the ivory pots of Nimrod, dating back to the beginning of the first millennium B. C. (Curtis \& Reade, 1995).

\subsection{A Plate of Bronze}

A plate of bronze was found in Nimrod, northern Iraq. The height of the plate is $2.55 \mathrm{~cm}$. the diameter of the plate is $21.85 \mathrm{~cm}$. it is currently preserved in the British Museum under the No. ME N 1, dating back to the beginning of the first millennium B. C. (Figure 7).

The plate has intricate inscriptions (Curtis \& Reade, 1995) and is decorated with an geometric shape. It was designed in the form of high - relief sculpture or low relief sculpture from the base of the plate. The plate was decorated with various floral ornamental and silver (Reade, 1989). There was a star in the middle of the plate, which was surrounded by animal drawings such as goats (Barnett, 1965). 


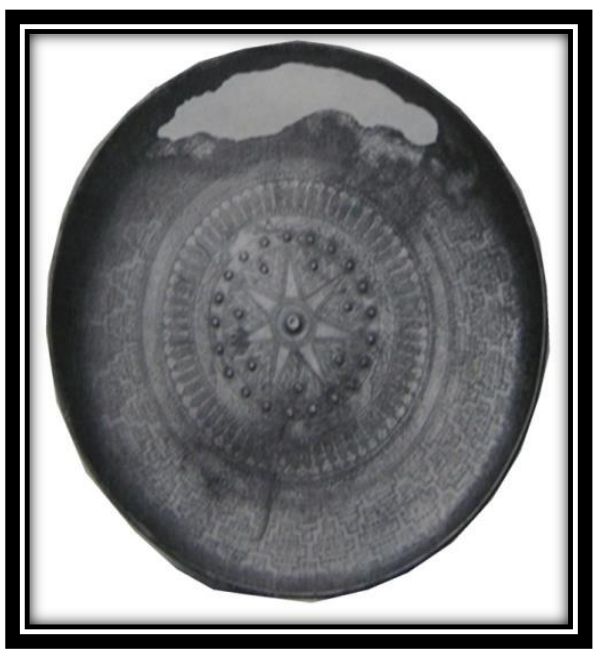

Figure 7.

\subsection{A Pot of Bronze}

A pot of bronze was found in Nimrod. The height of the pot is $2.85 \mathrm{~cm}$ and its diameter is $21.70 \mathrm{~cm}$. it is now preserved in the British Museum under No. (N 9), dating back to the beginning of the first millennium BC. Reade believes that the pot has high- relief ornaments with Egyptian influences (Curtis \& Reade, 1995). These ornaments are four pairs of winged falcons in the form of the Sphinx wearing the double crown of Upper and Lower Egypt. Such pots were found on the Assyrian inscriptions (Collon, 1995). There were pictures of the Assyrian Kings, who hold these pot. It is noted that every winged animal corresponds to the other animal. There are also two men lifting both hands, with a pole in the center, as if they are worshiping to the palm (Barnett, 1965). It is also noted that both opposite animals place one of their legs on the head of each man (Smith, 1928). The middle of the pot was decorated by a beautiful flower. It is likely that this pot reached Nimrod via one of the royal camps in the west, on the Phoenician coast (Figure 8) (Qates, 2001).

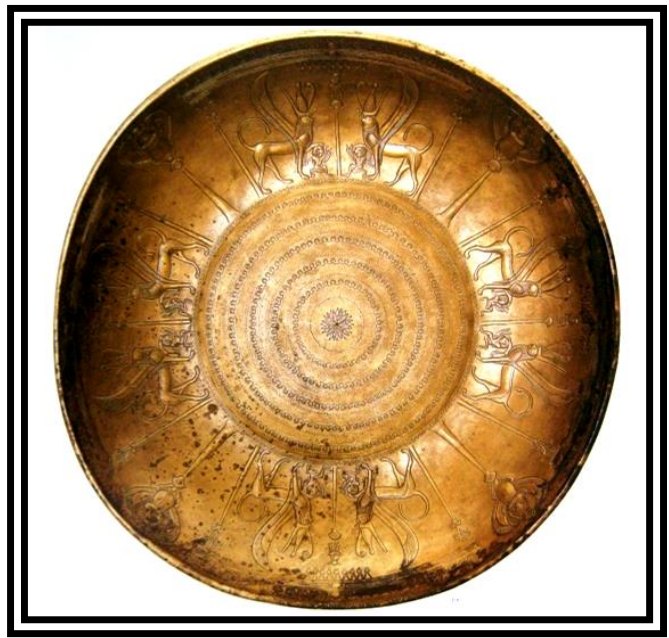

Figure 8.

\subsection{A Plate of Copper}

A plate of forged copper was found inside the Babylonian tombs, in Nippur. The height of the plate is $3.75 \mathrm{~cm}$. the diameter of the plate is $19.5 \mathrm{~cm}$. (Figure 9).

It was found under the surface by four meters. The plate was decorated with large circular motifs at the upper edge of the plate. There was a flower in the center of the plate. The flower was surrounded by several small circular shapes. There was a blooming flower like lotus flower which separates between each large circle at the edge (Peters, 1897).

Some believe that the artistic subjects, which emerged on some of the pots in Mesopotamia, were affected some of the Syrian art, while some other pots was affected by the Egyptian art. Curits thinks that animal ornamental motifs, which was found on the pot in figure 5 had a Syrian effect. However, the study sees that these motifs had 
an Egyptian effect and they came to Syria afterwards. The pot dated back to the beginning of the first millennium B.C. (Curtis, 1995).

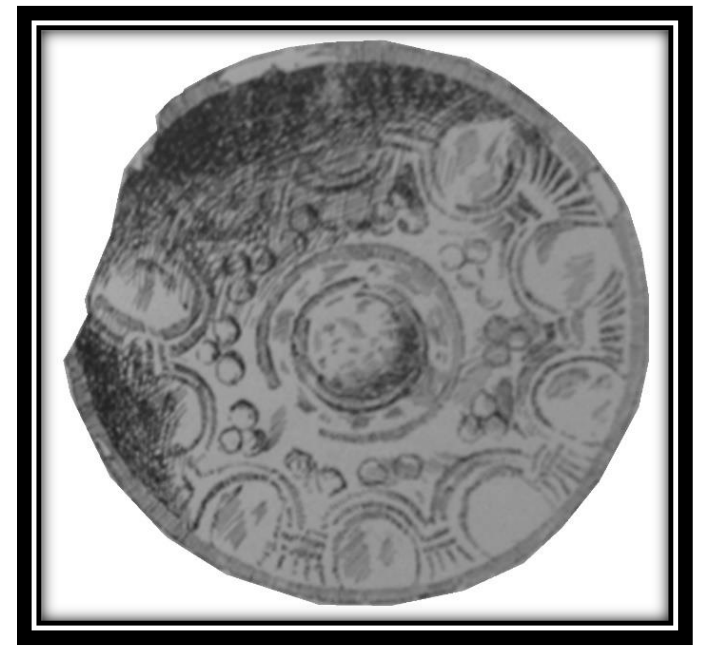

Figure 9.

\section{Inscribed Metal Pots in Ancient Egypt}

\subsection{A Pot of Silver}

A pot of silver found at Bubastis (Tell- Basta). The diameter of the pot is $20.5 \mathrm{~cm}$. and its depth is 6.5. the pot is now preserved in the Metropolitan Museum, New York, under No. 07.228.20.233 (Figure 10), dating back to the era $19^{\text {th }}$ family, a modern state. It contains ornaments on four contains two opposite rows of cattle and a man standing as a leader of horses, holding a rope in his hand and a crooked stick in his like bayonet in the his another hand (Al- Hawaily, 2006). The third scene contains two short palms and two large ones that were used as separations between the scenes.

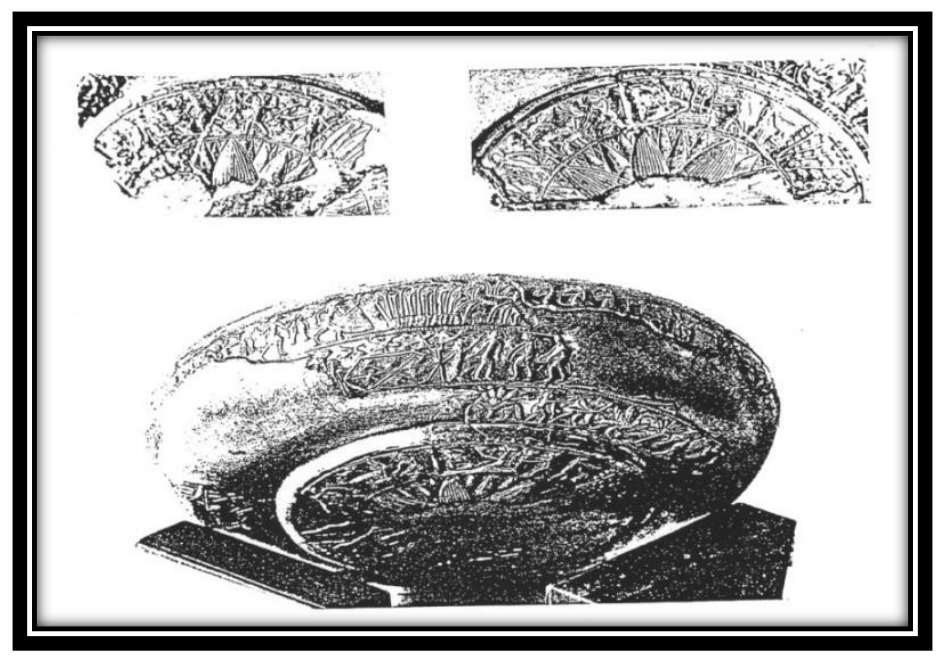

Figure 10.

\subsection{Plate of Leader Gehoti}

This plate was found inside the Cemetery of Gehoti Hotep, No. 11 in Western Thebes. It is a pure gold. The diameter of the plate is $17.9 \mathrm{~cm}$ and its height is $2.2 \mathrm{~cm}$. the weight of the plate is 371.5 grams. It is dated back to the era of King Thutmose III- modern state (Al- Hawaily, 2006). It is currently preserved in the Louvre Museum under No. 713. The plate has been granted to leader Gehoti by King Thutmose for his glorious military actions (Ziegler, 2002), (Figure 11).

It is noted that the center of the plate was decorated with rosetta flower. There were six tilapia fish swimming around the flower. This is one of the Egyptian influences that moved to Mesopotamia, and from there to the Arab Gulf. This scene may refer to a religious significance, which is re- birth and offspring. This may be consistent with the belief of the ancient Egyptian and his belief in the idea of resurrection and immortality, the continuation 
of the life after death (Radwan, 1969).

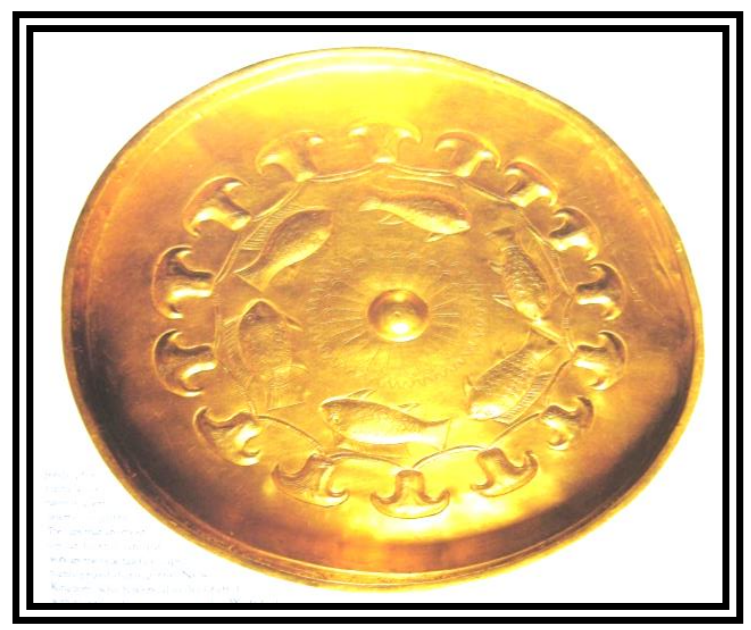

Figure 11.

\section{Conclusion}

The current study sheds light on some of inscribed metal pots in the West of the Arab Gulf (Mleiha and AlFueda) and showing human, geometric, animal and floral ornaments that appeared on these pots. The stud has compared the pots of Mleiha and Al- Fueda with the pots in civilization of both Mesopotamia and ancient Egypt. The Egyptian influences on these pots were evident. The most prominent of these influences are circular flowers and plants. The study has showed that the origin of the ornament of flowers and plant structures, which spread in ancient civilizations were of ancient Egyptian origin. Some scholars opposed the idea that ancient Egypt derived these decorative elements from Mesopotamia. In fact, most of scientists confirmed that these ornaments have ancient Egyptian origins.

The flowers of Chrysanthemum and Rosetta and blooming flowers appeared in both Mleiha and Al- Fueda. Rosetta flower is one of the most important artistic elements that decorated the middle of the pots. The ancient Egyptian gradually developed these ornamental motifs of Rosetta flower, which became similar to margarita flower. The lotus flower was commonly used in ornamental of ancient Near East and was more common in Mesopotamia. The lotus flower in Assyria showed the greatness of its holder. But, this flower symbolized rebirth and life in ancient Egypt.

Furthermore, plant ornamental motifs, trees and palms, which emerged as line between plant and animal ornaments such as the emergence of a person before palm, may symbolize the picture of god. In particular, palm symbolized the picture of god. The Dilmuni artist derived this tree to give the spirit of the locality. The palm represents the tree of life in the arts of the ancient Near East. Also, it represents god Enzak, the son of god Enki, who was god in the Arab Gulf.

In addition, the winged shapes had a significant effect in the pots of Mleiha where some arts of ancient Near East, especially the arts of Mesopotamia and Syria, quoted from the Egyptian art the style of the winged shapes. Also, opinions about the style of jumping animals in the air, which escape from their attackers.

Also, depiction of animals walk was affected by the same artistic style of ancient Egyptian artistic school, which moved to the Arab Gulf via Mesopotamia. Additionally, the spread of drawings, which represent running animals as horses in the west of the Arab Gulf, were derived from the arts of Syria, Mesopotamia nad ancient Egypt.

Accordingly, the study has reached many conclusions, the most important of which are: 1) The study noted the appearance of inscribed pots in the west of the Arab Gulf, which have ornaments depicting the scenes of hunting, fighting, mitary wheels, warriors, opposite animal monsters and human, animal and floral ornamental motifs, which was derived from Mesopotamia and Ancient Egypt. 2) The study noted the prevalence of scenes that represent winged animals shapes, horses, camels and cows in the west of the Arab Gulf, which dating back to the millennium B.C. Similar pots were found in ancient Near East countries, especially Mesopotamia and Ancient Egypt, which knew these subjects since the second millennium B.C. 3) The study showed that the appearance of the Rosetta flower on the pots was of Egyptian origin. 4) The pots and plates were decorated with splendid inscriptions and ornaments, and their themes were quoted from neighboring countries. 5) The study noted that some metal inscriptions represented the pure local environment of the art at the time. Also, some of them were 
affected by the arts of neighboring civilizations in Mesopotamia, Syria and ancient Egypt. 6) The study noted opinions about the style of representing the jumping animals in the air to escape from their attackers were different. Some see that the style of the movement of rapid and jumping animals is the style of the Aegean art that began in pre- modern times. While Kantor thinks that the style of depicting animals jumping in the air appeared first in the Egyptian arts from the pre- family period until the end of the middle state, and during the era of the modern state.

\section{References}

Al-Hawaily, S. (2006). Arts and Metal Industries in the Countries of the Ancient Near East and their Counterparts in Egypt since the beginning of the Middle Country to the End of the Modern Country (In Arabic) (Unpublished doctoral dissertation). Cairo: Faculty of Archeology.

Barnett, R. D. (1965). Layard Nimrud Bronze and There Inscriptions. Ertz - Israel 8.

Boucharalat, R., \& Mouton, M. (1991). Cultural Change in the Oman Peninsula during the Late ist Millennium B. C. As seen from Mleiha, Shajah, Emirate (UA6). PSAS, 12, 26-27.

Boucharlat, R., \& Jarczynske, P. (1988). The Mleiha Area: An Archaeological Map (ASISE, 4, p. 64, Figs. 27-14, 15.).

Collon, D. Ancient New East Art. London.

Curtis, J. E., \& Reade, J. E. (Eds.) (1995). Art and Empire: Treasures Assyria in the British Museum (p. 138, Fig. 101). London.

Keimer, L. (1924). Die Gartenpflanzen im Alten Ägypten. Berlin: Band I.

Kontor, H. J. (1947). The Aeganad the Orient in the Second Millennium B. C. Archacology and Fin Arts Spansord, 4, 62-76.

Mounton, M., Boucharlat, R., \& Jarczynske, P. (1989). Excavations at Mleiha, The Third Season. ASIE, 5, 44-45. Figs. 23-3, 24-1, 2.

Paul, Y., \& Charlotte, B. (2001). Al- Fueda Near Amla, Sultanate of Oman. PSAS, 31, 21-22. Fig. 8.

Peters, J. P. (1897). Nippur II (p. 384, pl. IV, Fig. 1.). London,

Qates, J. D. (2001). Nimrud: An Assyrian Imperial City Revealed (p. 246, Fig. 156.). London.

Radwan, A. (1969). Die Darstellungen des Regiernden Königs und Seiner Familienangehörigen in den Privatgräbern der 18. Dynastie, MÄS 21.

Reade, J. E. (1989). Fragment of Assyrian Monuments. Iraq XLIII, part II.

Smith, S. H. (1928). Babylonian Art. London.

Ziegler, C. (2002). The Pharaohs, United Kingdom. London.

\section{Copyrights}

Copyright for this article is retained by the author(s), with first publication rights granted to the journal.

This is an open-access article distributed under the terms and conditions of the Creative Commons Attribution license (http://creativecommons.org/licenses/by/4.0/). 